\title{
The Pandemic and Shareholder Value
}

\author{
Calin Valsan*
}

\begin{abstract}
Shareholder value has driven corporate governance in North America for over a century. In the wake of significant financial crises and growing inequalities, corporate America decided in 2019 to embrace a more egalitarian model, in which all stakeholders matter equally.

The brutal pandemic that wreaked havoc in the first half of 2020 exposed a startling disconnect between the real economy and the stock market. This disconnect is due to a gap between explicit and implicit corporate governance. While officially corporate America wants to convert to a new doctrine, the pandemic has shown that shareholder capitalism has remained the default model. Good intentions and official declarations are not enough in a system that has been specifically designed to serve the shareholders.

If stakeholder capitalism is to succeed, it needs a clear normative content and perhaps a more radical reform of institutions and regulation.
\end{abstract}

Keywords: Shareholder Value; Corporate Governance; Stakeholders; Stock Market; Pandemic; Global Markets

\section{Stakeholder Capitalism and Shareholder Capitalism}

For more than half century of "Greed is good," the North-American version of shareholder capitalism (aka shareholder value, or shareholder primacy) has delivered solid economic growth and prosperity. This growth, however, has been punctuated by violent financial crises that can be traced back to investor greed and corporate excesses. It also produced mega-corporations with valuations comparable to the GDP of major nations, wielding incredible economic power, dominating entire markets, and resulting in widening economic inequalities.

After years of edging closer to espousing a more socially responsible model of governance, corporate America decided in 2019 to officially embrace managing for all stakeholders, signaling a major shift in the core capitalist doctrine. In retrospect, it was a poor timing because a few months later, a world pandemic exposed the reallife challenges of this ideological conversion.

Economies across the world buckled under the weight of the lockdown, quarantine, and other restrictions aimed at containing the spread of the virus. In March 2020,

\footnotetext{
* Full Professor of Corporate Finance, Williams School of Business, Bishop's University, Canada (cvalsan@ubishops.ca)

Edited by: Niccolò Cusano University

ISSN: 1593-0319

Valsan, C. (2021). The Pandemic and Shareholder Value. Symphonya. Emerging Issues in Management (symphonya.unicusano.it), (2), 55-67.

https://dx.doi.org/10.4468/2021.2.06valsan
} 
stock markets plunged along with the economy but reversed course and started a spectacular recovery well into the beginning of August, when they erased almost all the losses incurred a few months earlier. This staggering comeback flies in the face of major economic indicators, such as GDP, unemployment, and industrial production, still reeling from the shock and still facing a very uncertain future.

The aim of this paper is to use the anecdotal evidence gathered so far on the disconnect between financial markets and the real economy in order to evaluate the extent to which the current model of corporate governance has succeeded in implementing its acknowledged ideological conversion. It is contended that the acute perception of disconnect between Main Street and Wall Street is due to a gap between expectations and reality. One wishes corporate boards give equal consideration to customers, employees, suppliers, and the local community, but in reality the fortunes of corporations continue to be driven almost entirely by the cash flow accruing to shareholders. In a system designed to cater to shareholders, it is hardly surprising to observe shareholder capitalism enduring against our best intentions. The transition to stakeholder capitalism might require a more radical reform of markets, institutions, and regulation, but it is not clear if society at large is ready for such a momentous challenge. The current situation is somewhat reminiscent of the challenge faced some thirty years ago by Mikhail Gorbachev's glasnost and perestroika, but this time in reverse.

\section{The Fortunes of Shareholder Capitalism}

Shareholder value has underpinned the current model of corporate governance for almost a century. The concept that shareholders are the most privileged claimholders has been enshrined into law by the famous 1919 Dodge v. Ford Motor Company ruling (Henderson, 2007), later summarized by Milton Friedman in an even more famous pronouncement: The responsibility of business is to maximize its profits (Friedman, 1970)

The doctrine of shareholder primacy is the cornerstone of shareholder capitalism and is predicated on four arguments: property rights, functionality, efficiency and contract incompleteness. The first argument is somewhat convoluted, but in essence it argues that if the initial appropriation of resources has been legitimate, then any market transaction following from here is also legitimate (Kymilcka, 1989). Functionality contends that managers cannot have conflicting loyalties, and need a clear metric of performance, that is, the share price. The argument from efficiency is built around Ronald Coase's transaction costs conjecture (Coase, 1960). Contract incompleteness argues that shareholders are the most vulnerable claimholders, because writing a complete contract is prohibitively expensive (Hart \& Moore 1988, 1990). Sometimes, efficiency and contract incompleteness are conflated into the tidethat-lifts-all-boats argument (Bainbridge, 2002).

The fate of shareholder primacy has ebbed and flowed, yet in the last quarter of the $20^{\text {th }}$ century it made a strong comeback and ended the century dominant and unchallenged. In the first two decades of the new millennium, the dot.com bubble and the sub-prime meltdown cast a long shadow, and fresh criticism -sometime quite virulent - was leveled at its conceptual foundation. Things finally came to a head in 2019 when the Business Roundtable, one of the most prestigious gatherings of Big 
Business CEOs, decided to denounce and renounce shareholder value altogether. The purpose of the corporation was updated under a new set of guidelines that strive to give equal consideration to all stakeholders:

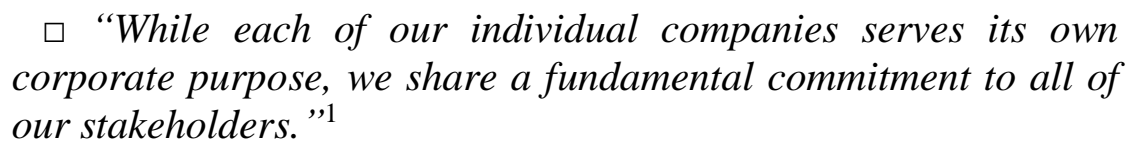

The stakeholders specifically identified in the report are: customers, employees, suppliers, local communities, and lastly, shareholders. It is not clear if this change of heart was prompted by the concern that shareholder capitalism is prone to devastating financial crises, or by moral concerns stemming from growing inequalities. Since inequalities increase the risk of social unrest and even economic crises, everything can be reduced to long-term sustainability.

Making an ideological pronouncement is one thing, putting it into practice is another one (Civera \& Freeman, 2019). It is likely that CEOs want to free themselves from the tyranny of capricious stock prices, but they also want to hold on to the substantial compensation packages buoyed by stock markets. Perhaps, the more relevant concern has to do with the system of corporate governance that was painstakingly build over the last one hundred years around shareholder value. How difficult would be to dismantle shareholder capitalism within a governance framework that was specifically designed to serve it? The challenge is not totally insurmountable, and there are precedents: in the late 1980s, Mikhail Gorbachev has successfully dismantled the communist regime from within, although arguably his intention was to reform it, not to destroy it (Satter, 2001). Here, we are dealing with a somewhat similar situation. Shareholder capitalism is perceived to be in a state of crisis, and needs to be reformed. Can it be done? The first test of how far corporations moved away from shareholder value has come amid an unexpected and brutal world pandemic.

\section{The Economy}

The crisis began at the end of 2019 in China, but by February 2020 it spread to Europe and North America. By mid-March, most countries had entered a partial lockdown or have implemented restrictions, such as social distancing, and/or the wearing of masks. Air travel, non-essential retail, restaurants, bars, tourism, concerts, and public gatherings were seriously curtailed. Parts of the world economy came to a grinding halt. The most dramatic period of the pandemic lasted until the end of April. By the beginning of May, the economy entered a period of slow recovery and by the end of May many countries began to ease the more draconian restrictions, such as the lockdown and quarantine. Social distancing and the wearing of mask remained the norm.

The economic impact of the pandemic was significant and immediate. The US Commerce Department estimated that in the second quarter of the year the US economy contracted by almost $33 \%$ on an annualized base, the most severe decline since 1947, when the record began (Thomson Reuters · Jul 30, 2020). Unemployment jumped from a low of $3.5 \%$ in February to $14.7 \%$ in April, only to recede to $11 \%$ in 
June, according to the US Bureau of Labor and Statistics. Canada's economy, even after it picked up in May and June, remained at $15 \%$ below its pre-crisis levels on an annualized basis. (Pete Evans 2020). Unemployment peaked at $13.7 \%$ in May, according to Statistics Canada.

The European Union also experienced a severe economic decline in the second quarter of 2020 -almost $12 \%$ on an annualized basis. Some countries fared better than others. Germany saw a $10 \%$ contraction, Italy experienced a $12.4 \%$ decline, France $13.8 \%$, and Spain - among the hardest hit, saw its GDP plunge by $18.5 \%$ in the second quarter, after it had already contracted by more than $5 \%$ in the first quarter ${ }^{2}$. Industrial production in the EU increased by $11.4 \%$ in May 2020 after a decrease by $18.2 \%$ in April and by $10.8 \%$ in March. The total reduction since February 2020 amounts to $18.8 \%$.

Unemployment averaged $7.1 \%$ across the European Union, but youth unemployment stood at $16.8 \%$. Greece, Spain, Cyprus and Lithuania showed above average unemployment, with Spain, again, holding the record at $15.6 \%$. It becomes increasingly clear that economies relying on services and tourism are among the hardest hit.

Public finances worsened because deficits and public debt increased due to a slowdown in economic activity and generous stimulus packages put forward by governments in the European Union, United States, Canada, and other countries. In the European Union, consolidated national debt stood at 79.5\% at the end of March, according to Eurostat. Several countries registered levels well above this average: Greece had the highest national debt to GDP ratio at $176 \%$, followed by Italy with $137 \%$, Portugal with $120 \%$, and Belgium 104\%. The United States reached levels comparable to those of Belgium, while Canada stood at $48.4 \%{ }^{3}$. This figure appears low in comparison to national debt levels in the United States because it excludes provincial debt.

Some worry that the global economic effects of the ongoing pandemic are underestimated because we rely too much on historical comparisons to previous crises, such as SARS and the 2008/2009 financial crisis (Nuno, 2020).

\section{The Stock Market}

North-American markets plunged spectacularly in mid-March but recovered almost miraculously by the beginning of August. Arguably, it was among the shortest bear market ever. The wild gyrations of the stock market are due in great part to the implementation of government restrictions and social distancing in almost every country in the world, and later by the adoption of a substantial stimulus package in the European Union and the United States (Baker et al., 2020; Ramelli \& Wagner, 2020; Zhang et al., 2020). Markets in Asia underperformed relative to North America (Liu et al., 2020). Interestingly, as the crisis progressed, it appears that the negative stock reaction was following more closely the number of declared cases rather than the number of deaths (Ashraf, 2020). There have been attempts to divide the period before and after the crisis began into distinct segments, each one with its own market dynamic - in terms of share price and volatility (Wagner, 2020; Altig et al., 2020; Onali, 2020). 
Before the pandemic hit Europe and the US, the S\&P 500 index hovered around 3,400 . In mid-March, it bottomed out at 2,200, a decrease of over $35 \%$. By the end of July it bounced back to above 3,270. The Dow Jones Industrial Average was hovering around 29,000 in February and tumbled to under 19,000 in mid-March - a drop of almost $35 \%$. By the end of July, it had recovered most of its losses and stood at 26,428. Growth continued into the first half of August. The tech-heavy NASDAQ Composite Index represents the more interesting case: it plunged from 10,700 before March to 7,000 in mid-March, but by the end of July had surpassed its pre-pandemic high and closed at 10,745. Of course, not all stocks fared in the same manner.

Tech stocks - usually viewed as risky - turned out to be the better performers as everyone moved their lives online. Even before the crisis started, Apple, Amazon, Microsoft, and Alphabet had surpassed the \$1 trillion market capitalization threshold. In the second quarter, these companies strengthened even more their dominant market position. Together they make up about $20 \%$ of the S\&P 500 Index and have a combined market capitalization of almost $\$ 5$ trillion - a figure that is comparable to the annual GDP of Japan, $40 \%$ of the annual GDP of China, and $25 \%$ of the annual GDP of the United States. Amazon had one the strongest quarters in recent history with $\$ 89$ billion in revenues, which represents a $40 \%$ increase over the previous year, and $\$ 8$ billion more than Wall Street was expecting. Analysts are speculating that by the end of 2020 the market capitalization of Apple will surpass the \$2 trillion mark. (Horowitz, 2020). Along these four giants, other tech-related, and online retailers made a strong showing. Netflix went from $\$ 385$ a share on February 19, to $\$ 299$ on March 16, and closed at $\$ 489.38$ on July 31, 2020. The lesser-known Zoom - that is, until people started to work from home - jumped from $\$ 70$ a share in mid-January to $\$ 107.47$ on March 12, and closed at $\$ 253.94$ on July 31. This represents a $263 \%$ appreciation since the beginning of the year. Wal-Mart went from $\$ 105$ a share in January to $\$ 104$ on March 12, only to close at \$129.45 on July 31. Among biotech firms, several performed extremely well: Novavax surged from below $\$ 10$ in January to $\$ 143$ on July 31 .

Of course, there were losers. The Dow Jones Transportation Average plunged from about 11,000 in January to 6,000 in March, only to recover somewhat and close at just under 10,000 on July 31. Airlines, cruise companies and hotels were among the hardest hit. Delta Airlines plunged from $\$ 62$ a share on January 17 to $\$ 21.51$ on March 19, and closed at $\$ 24.97$ on July 31. United Airlines had a similar fate: from $\$ 89.54$ on January 17 , it dropped to $\$ 21.28$ on March 19 , briefly jumped to $\$ 48.69$ on June 8 , to close at $\$ 31.38$ on July 31 . Hilton Worldwide Holdings went from $\$ 113.92$ on January 17 to $\$ 55.94$ on April 3, and closed at $\$ 75.02$ on July 3 . Norwegian Cruise Line Holdings fell from $\$ 59$ on January 17, to $\$ 8$ on March 17, and closed at $\$ 13.64$ on July 31 .

\section{The Disconnect Between the Economy and the Stock Market and What It Means for Corporate Governance}

In June 2020, the International Monetary Fund issues a Global Financial Stability Report in which it warns about a growing disconnect between financial markets and the real economy (International Monetary Fund, 2020). 
$\square$ "Risk asset prices have rebounded following the precipitous fall early in the year, while benchmark interest rates have declined, leading to an overall easing of financial conditions [...] Amid huge uncertainties, a disconnect between financial markets and the evolution of the real economy has emerged, a vulnerability that could pose a threat to the recovery should investor risk appetite fade."

During an August $11^{\text {th }}$ interview with CNN, JPMorgan Chase (JPM) CEO Jamie Dimon worries that the stock market does not reflect America's pain ${ }^{4}$ :

$\square$ “When you have 13 million people out of work, and you've got people suffering and small business suffering, that's far more important than the vicissitudes of Wall Street [...] That's what we should worry about."

On July $12^{\text {th }}$, the Washington Post notes that financial markets and the economy have parted ways ${ }^{5}$ :

$\square$ "It is impossible not to marvel at the apparently indestructible gap between the buoyant stock market and the less-than-buoyant real economy of workers, companies and jobs. One must say 'apparently indestructible', because maybe there is some simple and obvious explanation that eludes your correspondent. Otherwise, either the stock market is too high, or the economic outlook is too low. One or both must be wrong."

Even a May $8^{\text {th }}$ posting on NASDAQ's website discusses the perceived disconnect between Main Street and Wall Street (Mian, 2020).

There is a wide-spread current of opinion shared by large investment firms, journalists, and academics that acknowledge a perceived disconnect between Main Street and Wall Street (Sonders, 2020). In spite of never-ending bad news about growth in infections and economic decline, markets seem able to defy gravity, raising questions about what might be causing this phenomenon.

The Visual Capitalist attempts to assess the disconnect between the economy and the stock market by comparing and contrasting the change in the index of consumer sentiment to the change in the S\&P500. While this is not a rigorous empirical research, the insights are very telling. It certainly looks like consumer confidence is sinking while the S\&P500 is soaring (Lu, 2020).

However, a stock index that is heavily weighted in seven of the largest corporations in the world - Apple, Amazon, Microsoft, Google, Facebook, and Netflix (FAANGM henceforth) is obviously driven by the performance of these stocks. Since FAANGM have outperformed the market, the S\&P500 has also soared. When excluding FAANGM, market performance looks much more modest. It is very likely that another driver of stock market performance is the commitment of the Federal Reserve (and other central banks) to maintain liquidity by engaging in quantitative easing that now includes even corporate issues. With bond yields next to zero (and even negative) stocks become relatively more attractive. 
Economist Robert Shiller argues the divergence between market fundamentals and market outcomes is catalyzed by the dynamics of narrative epidemics and investor psychology who are driving a fear-of-missing-out market (Shiller, 2020).

When the pundits worry about the disconnect between Main Street and Wall Street they make an implicit assumption. If one expects the fortunes of capital markets to reflect the evolution of the real economy, one presupposes that the wealth and wellbeing of publicly listed corporations directly depend on market fundamentals such as unemployment, wages, industrial production, consumer sentiment, government deficits, and the like. While this assumption is generally true, it needs to be qualified. The wealth and well-being of publicly listed corporations do depend on market fundamentals, but the relationship is mediated by investor's expectations about the cash flows generated in the context of the crisis.

As already discussed above, after years of pursuing shareholder value that periodically ended in earnings restatements, mega mergers, multi-billion dollar IPOs, and financial crises, one of the most consequential doctrines of contemporary capitalism seems to have shifted its focus: Almost everyone agrees that from maximizing market value CEOs have to look after all stakeholders: consumers, suppliers, employees, the local community, debtholders and shareholders. It is implied that corporate governance should be equally concerned with the welfare of all these constituencies. But what does this mean in practice for the corporation? And how would a corporation that is managed for the benefit of all its stakeholders be assessed and valued during a pandemic like the one we are traversing right now?

Corporate governance deals with three important questions. The first issue has to do with the control of the organization. The second issue determines whose interest would ultimately prevail in the case of a zero-sum game. The last question dictates the manner in which the economic surplus - the object of the bargaining process among the claimholders of the firm - is defined and measured. Shareholder capitalism has answered unambiguously and clearly all three questions. The Board of Directors is the pinnacle of power and control, shareholders' interests have a preferred status, and the market value of shares is the ultimate metric of performance, subject to obeying the law.

The details of stakeholder value as opposed to those of shareholder value are more nebulous and vague. The Board of Directors retains its power, but must be diversified to reflect a broader constituency, and the interest of all stakeholders matter equally. The third question, however, is more or less eschewed. There are no universally recognized metrics of stakeholder performance, although there is no shortage of candidates, from corporate scorecards to environmental and social responsibility ratings (Ridwan et al., 2013; Kraus \& Lind, 2010; Strenger, 2004; Hoque \& Kaplan, 2012; Kaplan \& Nagel, 2004). The real problem with assessing and measuring the economic outcome when everyone is entitled to equal consideration comes down to producing a system of metrics that is meaningful - in that it reflects a diversity of interests, but does not generate dysfunctional behavior - in that it remains free of deception, internal contradictions, and conflict of interests (Cini \& Ricci, 2018).

Stakeholder value is obviously very far from having a rigorous normative content, but one would expect that whenever the stakeholders of the corporations are adversely impacted in a consistent manner across the board, the fortunes of the corporations should reflect this adversity. When a majority of supply chains are disrupted, a record number of people file for unemployment, small and medium 
business are on the verge of bankruptcy, industrial production, tourism, and restaurants are down, and whole communities are reeling, the stock market should move in sink with the majority who experience hardship. If the purpose of the corporation is the welfare of these constituencies across the board, there should be no disconnect between the economy and the stock market, and Main Street's pain should parallel Wall Street's pain.

In practice, Main Street's pain becomes Wall Street's pain only when Main Street's distress has a material impact on corporate cash flows. If the hardship experienced by the poor and the middle-class translate into larger profits and cash flows, then we observe a disconnect. If unemployment surges, but its main impact is to keep wages and labor costs low, the valuation of corporations surges as well. If production is down, but due to market dominance, some corporations are able to compensate a lower real output with higher prices, then obviously stock prices would go up as well. This is how shareholder value works. The management of a corporation would make choices that increase the present value of future cash flows. All the anecdotal evidence and some academic research we have so far about how corporations behave during the pandemic points in that direction.

We already know that not all stocks react in the same manner. Stocks that fell out of favor, such as energy, real estate, entertainment, and hospitality showed extreme asymmetrical volatility, had to cut pay to employees and managers, fired executives, but nevertheless allowed cash bonuses and generous compensation packages for selected executives. On the other hand, natural gas, food, healthcare, and software enjoyed solid returns, and in many cases insiders sold their equity stakes as the market price of shares was rising. (Mazur et al., 2021).

Using data on over 6,000 firms across 56 economies during the first quarter of 2020, a recent study finds that - notwithstanding exposure to the pandemic through global supply chains and customer locations - corporations with a better financial standing, and less entrenched executives experiences milder price declines - exactly as prescribed by shareholder value (Ding et al., 2020).

But all this accumulating anecdotal and systematic evidence is in some sense trivial. It helps explaining something akin to water flowing downhill. There is nothing to wonder about when firm value is the present value of future cash flows.

The observed disconnect perceived by a majority of observers appears ominous, and even outrageous because it reflects a gap between expectations and reality with respect to the underlying principles of corporate governance. While the public at large expects that managers do everything possible in order to make everyone better off, investors and corporate boards are busy keeping cash flows steady. The implicit model of corporate governance operational during the pandemic remains without a doubt shareholder value, in spite of everyone officially professing stakeholder wellbeing and corporate social responsibility.

In the first five months of the year, executives divested significant shareholdings in the companies that grew the fastest, such as Zoom and Netflix, cashing in tens of millions of dollars. Corporate executives have arguably a conflicted relationship with shareholder value. On the one hand, performance pay, which lies at the core of the current model of corporate governance, represents the ticket to multimillion-dollar compensation packages, especially during bull markets. On the other hand, CEOs must resent the arbitrariness of performance pay because market risk plays a large role in driving equity valuation, in spite of the many individual competencies and 
talents corporate executives might have. If pay for luck is real, then disrepute for misfortune must also be true. Even if CEOs embrace managing for stakeholders in good faith, they operate within a system of corporate governance that exerts tremendous pressure to comply with pursuing the valuation of stocks. This, above and beyond any other considerations. The current pandemic is showing that the transition to managing for stakeholders cannot take place just by wishing it. It requires a structural reform of corporate governance.

As a small consolation for the stakeholder model of corporate governance, Environmental and Social Stocks appear somewhat more resilient so far (Albuquerque et al., 2020). The effect, however, appears small and requires independent corroboration. Overall, it will take some time for the evidence to accumulate in order to conduct more comprehensive studies in a more dispassionate frame of mind. Until then it is fair to conclude that we are still under the strong spell of shareholder capitalism and far from the ideal of equal consideration for all stakeholders.

\section{Concluding Remarks}

If there is a disconnect between the economy and the stock market, this is most likely due to the gap between explicit and the implicit model of corporate governance. Without taking any sides in the ideological debate between shareholder and stakeholder capitalism, one must acknowledge that any discrepancy between explicit and implicit objectives results in a deeply dysfunctional organizational behavior. Government employees and public sector bureaucrats probably relate very well to this predicament. For decades, public health workers and university professors had struggled with ambiguity and cognitive dissonance: Nominally, the main objective has always been improving the general health of the population, caring for the sick, delivering excellence in education, imparting skills and building competencies. In practice, however, these objectives have always been adapted and twitched to meet budget constraints and enrollment targets, which in many situations took precedence over the more inspiring goals professed in the mission statement. Until recently, corporations suffered to a lesser extent from this dissonance, because the "greed is good," motto of shareholder capitalism during the last half century allows boards to drop any pretense.

The increasing pressure exerted on corporations and politicians from a wide range of constituencies facing growing economic inequalities and increasing Big Business dominance has changed the tide. A long trend of developments culminated in the year 2019 when Corporate America has made a historic and fateful pledge to put a lid on investor greed and embrace a more caring and socially responsible version of capitalism.

The ongoing Covid-19 pandemic has exposed the challenges facing this about-face, assuming the commitment to stakeholders and corporate social responsibility is more than a gimmick and a PR stint.

Good faith and honorable intentions are not enough when the entire internal and external system of corporate governance has been designed in order to deliver higher equity valuations for investors. 
Ironically, this situation is reminiscent of another famous transition. In the late 1980 s, it has become increasingly clear that reforming the command economy into a more humane form of communism could not be easily achieved, notwithstanding the idealism and good intentions of its reformers. No one knew how to do it, and every good faith attempt at reforms only made things worse. After the fall of the Berlin Wall, all post-communist nations in Eastern Europe proceeded with dismantling the command system and starting anew. In the early 1990s, the world moved away from the ideal of caring and the pretense of egalitarianism, towards embracing pragmatism and greed. Thirty years later, corporate America wishes to transition back, and finds there is no tried-and-tested recipe for a more human and socially responsible version of capitalism. The current move towards stakeholders and corporate social responsibility parallels Mikhail Gorbachev's perestroika and glasnost, but in reverse. Under the current conditions, dismantling the current system of corporate governance and starting anew is out of the question. Radical social engineering is not a palatable option, in spite of the vocal chorus of critics clamoring for change. Most people would settle for reformed model of corporate governance that would reduce inequalities while still delivering economic growth and prosperity.

But if managing for stakeholders is to have a real chance of success beyond pledges and nicely designed corporate websites, one needs to devise a normative system of performance metrics capable of making the good intentions behind the ideology operational.

\section{Bibliography}

Albuquerque, R., Koskinen, Y., Yang, S., \& Zhang C. (2020). Resiliency of Environmental and Social Stocks: An Analysis of the Exogenous COVID-19 Market Crash, The Review of Corporate Finance Studies, 9(3), 593-621.

http://dx.doi.org/10.1093/rcfs/cfaa011

Altig, D., Baker, S., Barrero, J. M., Bloom, N., Bunn, P., Chen, S., \& Thwaites, G. (2020). Economic Uncertainty Before and During the COVID-19 Pandemic. Journal of Public Economics, 191, 104274.

http://dx.doi.org/10.1016/j.jpubeco.2020.104274

Ashraf, B. Na. (2020). Stock Market's Reaction to COVID-19: Cases or Fatalities? Research in International Business and Finance, 54, 101249.

http://dx.doi.org/10.1016/j.ribaf.2020.101249

Bainbridge, S. M. (2002). Director Primacy: The Means and Ends of Corporate Governance. UCLA, School of Law Research Paper No. 02-06.

http://dx.doi.org/10.2139/ssrn.300860

Baker, S. R., Bloom, N., Davis, S. J., Kost, K. J., Sammon, M. C., \& Viratyosin, T. (2020). The Unprecedented Stock Market Impact of COVID-19. NBER Working Paper No. 26945, NBER Program(s): Asset Pricing, Economic Fluctuations and Growth.

http://dx.doi.org/10.3386/w26945

Brondoni, S. M. (2019). Shareowners, Stakeholders \& the Global Oversize Economy. The CocaCola Company Case, Symphonya. Emerging Issues in Management (symphonya.unicusano.it), (1), 16-27. http://dx.doi.org/10.4468/2019.1.02brondoni

Cini, A. C., \& Ricci, C. (2018). CSR as a Driver where ESG Performance will Ultimately Matter, Symphonya. Emerging Issues in Management (symphonya.unimib.it), (1), 68-75.

http://dx.doi.org/10.4468/2018.1.05cini.ricci 
Civera, C., \& Freeman, R. E. (2019). Stakeholder Relationships and Responsibilities: A New Perspective. Symphonya. Emerging Issues in Management (symphonya.unicusano.it), (1), 40-58.

http://dx.doi.org/10.4468/2019.1.04civera.freeman

Coase, R. (1960). The Problem of Social Cost. Journal of Law and Economics, 3, 1-44. http://dx.doi.org/10.1057/9780230523210_6

Ding, W., Levine, R., Lin, C., \& Xie, W. (2021). Corporate Immunity to the COVID-19 Pandemic. Journal of Financial Economics, 141(2), 802-830.

http://dx.doi.org/10.1016/j.jfineco.2021.03.005

Eurostat. Various statistics.

https://ec.europa.eu/eurostat/web/covid-19/overview

Evans, P. (2020). Canada's GDP Bounced Back in May, but it was still 15\% below where it was before COVID-19. CBC News, July 31, 2020.

https://www.cbc.ca/news/business/canada-gdp-may-1.5670117

Fernandes, N. (2020). Economic Effects of Coronavirus Outbreak (COVID-19) on the World Economy. IESE Business School Working Paper No. WP-1240-E, Available at SSRN. http://dx.doi.org/10.2139/ssrn.3557504

Friedman, M. (1970). The Social Responsibility of Business is to Increase its Profits. The New York Times Magazine, September 13, 1970. http://dx.doi.org/10.1007/978-3-540-70818-6_14

Hart, Oliver \& Moore, John (1988). Incomplete Contracts and Renegotiation. Econometrica, 56, 755-785. http://dx.doi.org/10.2307/1912698

Hart, O., \& Moore, J. (1990). Property Rights and the Nature of the Firm. Journal of Political Economy, 98 (6), 1119-1158.

http://dx.doi.org/10.1086/261729

Henderson, M. T. (2007). Everything Old is New Again: Lessons from Dodge v. Ford Motor Company. University of Chicago Law \& Economics, Olin Working Paper No. 373, Available at SSRN.

http://dx.doi.org/10.2139/ssrn.1070284

Hoque, Z., \& Kaplan, R. S. (2012). The Balanced Scorecard: Comments on Balanced Scorecard Commentaries. Journal of Accounting \& Organizational Change, 8 (4), 539-545.

http://dx.doi.org/10.1108/18325911211273527

Horowitz, Julia (2020). Big Tech's 'Staggering' Earnings Live Up to Market Hype. CNN Business, Fri July 31.

https://www.cnn.com/2020/07/31/investing/premarket-stocks-trading/index.html

International Monetary Fund (2020), Global Financial Stability Report Update: Financial Conditions Have Eased, but Insolvencies Loom Large. June.

https://www.imf.org/en/Publications/GFSR/Issues/2020/06/25/global-financial-stability-reportjune-2020-update

Kaplan, R. S., \& Nagel, M. (2004). Improving Corporate Governance with the Balanced Scorecard. Working paper 04-044.

Kraus, K., \& Lind, J. (2010). The Impact of the Corporate Balanced Scorecard on Corporate Control - A Research Note. Management Accounting Research, 21(4), 265-277.

http://dx.doi.org/10.1016/j.mar.2010.08.001

Kymilcka, W.1 (1989) Contemporary Political Philosophy. Oxford, UK: Clarendon Press.

Liu, H., Manzoor, A., Wang, C., Zhang, L., \& Manzoor, Z. (2020). The COVID-19 Outbreak and Affected Countries Stock Markets Response. International Journal of Environmental Research and Public Health, 17, 2800.

http://dx.doi.org/10.3390/ijerph17082800

Lu, M. (2020). Understanding the Disconnect Between Consumers and the Stock Market. Posted on The Visual Capitalist on July 29.

https://www.visualcapitalist.com/understanding-the-disconnect-between-consumers-and-thestock-market/

Edited by: Niccolò Cusano University

ISSN: $1593-0319$ 
Mazur, M., Dang, M., \& Vega, M. (2021). COVID-19 and the March 2020 Stock Market Crash. Evidence from S\&P1500. Finance Research Letters, 38, 101690.

http://dx.doi.org/10.1016/j.frl.2020.101690

Mian, Sheraz (2020). Is Wall Street Oblivious of Main Street Pain? May 8.

https://www.nasdaq.com/articles/is-wall-street-oblivious-of-main-street-pain-2020-05-08

Onali, Enrico (2020). COVID-19 and Stock Market Volatility. Working paper, available at SSRN.

http://dx.doi.org/10.2139/ssrn.3571453

Ridwan, R., Harun, H., An, Y., \& Fahmid, I. M. (2013). The Impact of the Balanced Scorecard on Corporate Performance: The Case of an Australian Public Sector Enterprise. International Business Research, 6(10), 103.

http://dx.doi.org/10.5539/ibr.v6n10p103

Salvioni, D. M., \& Gennari, F. (2019). Stakeholder Perspective of Corporate Governance and CSR Committees, Symphonya. Emerging Issues in Management (symphonya.unicusano.it), (1), 28-39.

http://dx.doi.org/10.4468/2019.1.03salvioni.gennari

Satter, D. (2001). Age of Delirium: The Decline and Fall of the Soviet Union. Yale University Press.

Shiller, Robert J. (2020). Understanding the Pandemic Stock Market. July 7.

https://www.project-syndicate.org/commentary/understanding-us-pandemic-stock-market-byrobert-j-shiller-2020-07?barrier=accesspaylog

Sonders, Liz A. (2020). Disconnect the Dots: Main Street vs. Wall Street. June 1.

https://www.schwab.com/resource-center/insights/content/disconnect-dots-main-street-vs-wall-street

Statistics Canada. Canadian Economic Dashboard and COVID-19. Various statics.

https://www150.statcan.gc.ca/n1/pub/71-607-x/71-607-x2020009-eng.htm

Ramelli, S. \& Wagner, A. F. (2020). Feverish Stock Price Reactions to COVID-19. The Review of Corporate Finance Studies, 9(3), 622-655.

http://dx.doi.org/10.1093/rcfs/cfaa012

Strenger, C. (2004). The Corporate Governance Scorecard: a Tool for the Implementation of Corporate Governance. Corporate Governance: An International Review, 12(1), 11-15.

http://dx.doi.org/10.1111/j.1467-8683.2004.00339.x

Thomson Reuters (2020). U.S. Economy Shrank at Fastest Pace on Record Last Quarter. July 30.

https://www.cbc.ca/news/business/us-gdp-economy-1.5668589

US Bureau of Labor and Statistics. Various statistics.

https://data.bls.gov/timeseries/LNS14000000

Wagner, A. F. (2020). What the Stock Market Tells us About the Post-COVID-19 World. Natural Human Behavior, 4, 440.

http://dx.doi.org/10.1038/s41562-020-0869-y

Zhang, D., Hu, M., \& Ji, Q. (2020). Financial Markets Under the Global Pandemic of COVID-19. Finance Research Letters, 36, 101528.

http://dx.doi.org/10.1016/j.frl.2020.101528

\section{Notes}

1 Statement on the Purpose of a Corporation, https://opportunity.businessroundtable.org/wpcontent/uploads/2020/04/BRT-Statement-on-the-Purpose-of-a-Corporation-with-SignaturesUpdated-April-2020.pdf, accessed on May 6, 2020.

${ }^{2}$ Eurozone suffers deepest contraction on record, 31 July 2020, https://www.bbc.com/news/business53606101

${ }^{3}$ Kait Bolongaro and Shelly Hagan, Bloomberg News, https://www.bnnbloomberg.ca/budget-officersays-federal-deficit-could-top-252b-1.1429432 
SYMPHONYA Emerging Issues in Management, 2, 2021

symphonya.unicusano.it

\footnotetext{
${ }^{4}$ Paul R. La Monica, Jamie Dimon: The stock market doesn't reflect Americans' pain, CNN Business, Updated 8:00 AM ET, Tue August 11, 2020, https://www.cnn.com/2020/08/11/economy/jamiedimon-nyc-minority-jobs/index.html

${ }^{5}$ https://www.washingtonpost.com/opinions/the-stock-market-and-economy-have-parted-ways-its-afomo-market-now/2020/07/12/c14246d8-c2bf-11ea-b4f6-cb39cd8940fb_story.html
} 